Article

\title{
Microbial Fuel Cell with Ni-Co Cathode Powered with Yeast Wastewater
}

\author{
Paweł P. Włodarczyk * (D) and Barbara Włodarczyk \\ Faculty of Natural Sciences and Technology, Institute of Technical Science, University of Opole, \\ Dmowskiego str. 7-9, 45-365 Opole, Poland; barbara.wlodarczyk@uni.opole.pl \\ * Correspondence: pawel.wlodarczyk@uni.opole.pl; Tel.: +48-077-401-6717
}

Received: 30 September 2018; Accepted: 14 November 2018; Published: 17 November 2018

\begin{abstract}
Wastewater originating from the yeast industry is characterized by high concentration of pollutants that need to be reduced before the sludge can be applied, for instance, for fertilization of croplands. As a result of the special requirements associated with the characteristics of this production, huge amounts of wastewater are generated. A microbial fuel cell (MFC) forms a device that can apply wastewater as a fuel. MFC is capable of performing two functions at the same time: wastewater treatment and electricity production. The function of MFC is the production of electricity during bacterial digestion (wastewater treatment). This paper analyzes the possibility of applying yeast wastewater to play the function of a MFC (with Ni-Co cathode). The study was conducted on industrial wastewater from a sewage treatment plant in a factory that processes yeast sewage. The Ni-Co alloy was prepared by application of electrochemical method on a mesh electrode. The results demonstrated that the use of MFC coupled with a Ni-Co cathode led to a reduction in chemical oxygen demand (COD) by $90 \%$ during a period that was similar to the time taken for reduction in COD in a reactor with aeration. The power obtained in the MFC was $6.1 \mathrm{~mW}$, whereas the volume of energy obtained during the operation of the cell (20 days) was $1.27 \mathrm{Wh}$. Although these values are small, the study found that this process can offer an additional level of wastewater treatment as a huge amount of sewage is generated in the process. This would provide an initial reduction in COD (and save the energy needed to aerate wastewater) as well as offer the means to generate electricity.
\end{abstract}

Keywords: microbial fuel cell; yeast wastewater; environmental engineering; renewable energy source; cathode; $\mathrm{Ni}-\mathrm{Co}$ alloy

\section{Introduction}

The food industry plays an important role in the economy of a country [1,2]. It often forms the driving force for other industry branches as well. Due to the fact that huge amounts of wastewater (WW) are generated as a by-product of yeast production, considerable investment is needed for its neutralization [3]. Therefore, attempts are constantly under way to seek the possibility of applying wastewater sludge as a source of energy or as a raw material for further use [4-6]. Studies conducted to this date have demonstrated that it is theoretically possible to derive 9 times more energy from wastewater compared to the energy needed to clean it $[7,8]$. The yeast industry is one of the branches of the food industry where large amounts of wastewater are generated $[9,10]$. The yeast industry plays a role not only in the production of baker's yeast but also as a source of substances with various applications in medicine, supplements used to boost the immune system, and in beauty products [11].

As wastewater is formed by a biological mixture, it is characterized by a high content of nitrogen, potassium, and organic substances; low content of heavy metals; and a constant composition (yet relative to the production technology) [12]. For this reason, sewage from the yeast industry can be, 
and often is, used in agricultural fields (AF) $[12,13]$. It would be reasonable to apply their enormous potential in the generation of useful energy before redirecting them in the fields. However, for this, the high concentration of COD in yeast wastewater needs to be first reduced. Microbial fuel cells (MFC) form bioelectrochemical systems that can simultaneously pretreat sewage (leading to a decrease in COD) and generate electricity $[4,6,14,15]$. Therefore, the use of MFCs forms a promising solution that can reduce the concentration of COD coupled with energy production from wastewater $[16,17]$. MFCs can be powered by both domestic wastewater and processed wastewater [18].

The bacteria that are capable of producing electrons during wastewater treatment play a key role in MFCs $[19,20]$. Examples of such bacteria include Geobacter, Shewanella, or Pseudomonas genera among others [21-28]. An analysis of reports in this field shows that the highest values of power are generated by MFCs comprising multispecies aggregates, where microorganisms grow in the form of biofilms. Mixed cultures seem to be solid and more efficient compared to single-strain cultures, and their isolation from natural sources is a much easier task. In contrast, the use of pure cultures has technical limitations, mainly due to the need to ensure sterile conditions for growth, and the process usually involves high costs [29].

A microbial fuel cell usually consists of an anode and a cathode separated by a semipermeable proton exchange membrane (PEM), which ensures anaerobic conditions in the anodic area [30]. The activity of an electrode (anode) determines the metabolism of bacteria. In conditions where the anode has a higher potential than other electron mediators available for bacteria, e.g., in the case of sulfides in the source of organic matter, it is the preferred electron mediator [31].

Research on the efficiency of MFCs technology is continuing, and efforts are being made to improve it. An unquestionable goal of research in this field is associated with the development of cells that are capable of producing the greatest volume of electricity with the lowest possible energy delivered into the system [32]. To achieve this, it is important to note the research aimed at increasing the activity of bacteria and electrode materials, e.g., with the use of cathode catalysts. MFCs can be applied to treat domestic wastewater (DWW) as well as industrial wastewater (IWW) [33,34]. The bacteria act as a biocatalyst in microbiological fuel cells [6]; therefore, coal (carbon cloth, carbon brush) is most often used as the anode material [6,35], while carbon materials and metal electrodes perform the role of cathodes. In addition, new electrode materials or catalysts are currently being sought to act as cathodes [36-39].

This paper reports the results of a study into the potential application of wastewater from the yeast industry in a MFC comprising Ni-Co cathode.

\section{Materials and Methods}

The measurements were carried out by application of wastewater samples from Lesaffre Polska yeast factory. The samples were derived from a wastewater treatment plant (WWTP) located in the factory. The plant policy provides that process wastewater is applied for irrigating farmland, which forms an integral part of the production. However, some of the wastewater from the process goes to a factory wastewater treatment plant with the purpose of ensuring an adequate development of microorganisms needed for the course of water treatment. The volume of process wastewater (PWW) applied at the input of the treatment process depends on many factors, e.g., the total amount of wastewater that enters the treatment plant or the volume of yeast production. Therefore, the waste applied in the treatment plant, which usually contains domestic wastewater and water derived from cleaning equipment, comprises a certain volume of PWW. Table 1 contains a summary of the parameters of WW applied in the measurements.

Table 1. Parameters of wastewater applied for measurements.

\begin{tabular}{cc}
\hline Parameter & Value \\
\hline $\mathrm{COD}\left[\mathrm{mg} \cdot \mathrm{L}^{-1}\right]$ & 3266 \\
$\mathrm{pH}$ & $6.5 \pm 0.1$ \\
\hline
\end{tabular}


The experimental part of the study involved the development of an electrode (cathode), preparation of an experimental setup, measurement of variations in COD concentration, and determination of microbial curves for the fuel cell.

A cathode with a Ni-Co catalyst was applied in the measurements of MFC. The cathode was prepared as a copper mesh with a catalyst coating. The catalyst (Ni-Co alloy) was applied by the electrochemical deposition method [40]. The composition of the mixture and parameters for electrochemical catalyst deposition is summarized in Table 2.

Table 2. Composition of the mixture applied for catalyst deposition (Ni-Co alloy) on the copper mesh.

\begin{tabular}{|c|c|c|c|c|c|}
\hline Component & $\begin{array}{l}\text { Volume } \\
{\left[\mathrm{g} \cdot \mathrm{L}^{-1}\right]}\end{array}$ & $\mathrm{pH}$ & $\begin{array}{c}\text { Temperature } \\
{[\mathrm{K}]}\end{array}$ & $\begin{array}{c}\text { Current Density } \\
{\left[A \cdot \mathbf{d m}^{-2}\right]}\end{array}$ & $\begin{array}{c}\text { Co Concentration } \\
{[\%]}\end{array}$ \\
\hline $\mathrm{NiSO}_{4} \cdot 7 \mathrm{H}_{2} \mathrm{O}$ & 260 & \multirow{4}{*}{3.0} & \multirow{4}{*}{293} & \multirow{4}{*}{1.6} & \multirow{4}{*}{15} \\
\hline $\mathrm{CoSO}_{4} \cdot 7 \mathrm{H}_{2} \mathrm{O}$ & 14 & & & & \\
\hline $\mathrm{H}_{3} \mathrm{BO}_{3}$ & 15 & & & & \\
\hline $\mathrm{NiSO}_{4} \cdot 7 \mathrm{H}_{2} \mathrm{O}$ & 200 & & & & \\
\hline $\mathrm{CoSO}_{4} \cdot 7 \mathrm{H}_{2} \mathrm{O}$ & 20 & \multirow{3}{*}{5.5} & \multirow{3}{*}{293} & \multirow{3}{*}{1.0} & \multirow{3}{*}{25} \\
\hline $\mathrm{H}_{3} \mathrm{BO}_{3}$ & 30 & & & & \\
\hline $\mathrm{NaCl}$ & 15 & & & & \\
\hline $\mathrm{NiSO}_{4} \cdot 7 \mathrm{H}_{2} \mathrm{O}$ & 195 & \multirow{3}{*}{2.0} & \multirow{3}{*}{293} & \multirow{3}{*}{3.0} & \multirow{3}{*}{50} \\
\hline $\mathrm{CoSO}_{4} \cdot 7 \mathrm{H}_{2} \mathrm{O}$ & 35 & & & & \\
\hline $\mathrm{NiSO}_{4} \cdot 7 \mathrm{H}_{2} \mathrm{O}$ & 140 & & & & \\
\hline $\mathrm{CoSO}_{4} \cdot 7 \mathrm{H}_{2} \mathrm{O}$ & 120 & \multirow{3}{*}{4.0} & \multirow{3}{*}{323} & \multirow{3}{*}{1.0} & \multirow{3}{*}{75} \\
\hline $\mathrm{H}_{3} \mathrm{BO}_{3}$ & 30 & & & & \\
\hline $\mathrm{NaCl}$ & 15 & & & & \\
\hline
\end{tabular}

The composition of the mixture was selected on the basis of experiments. During the application of the alloy, various concentrations of components $(\mathrm{Ni}, \mathrm{Co}$ ) were obtained (Table 2). The process of preparing the electrode for deposition involved degreasing the copper mesh in $\mathrm{KOH}$ solution and its etching in acetic acid and then washing with alcohol [41].

Initially, the study involved the measurements of COD reduction in the examined wastewater. This parameter provides a tool to evaluate the performance of MFCs. The measurements were carried out for three different reactors: one without aeration (Reactor 1), one with aeration (Reactor 2), and one conducted continuously in a working MFC (Reactor 3). An assumption was made that the measurements will be carried out to achieve a 90\% decrease in COD concentration [42,43]. In the reactor without aeration (Reactor 1), the wastewater had contact with air only through the wastewater-air interface. In the reactor with aeration (Reactor 2), wastewater was aerated with an air pump with a capacity of $270 \mathrm{~L} \cdot \mathrm{h}^{-1}$. In the third reactor (Reactor 3), the wastewater was treated (resulting from the reduction in COD concentration) as a consequence of applying MFC. COD measurements were conducted using the Hanna HI-83224 colorimeter (Hanna Instruments, Woonsocket, RI, USA). In the MFC, carbon cloth was used as the anode material, whereas the cathode was made of a metal mesh with a Ni-Co catalyst. The surface area of the anode was $30 \mathrm{~cm}^{2}$, while it was $15 \mathrm{~cm}^{2}$ for the cathode. The cathode was placed in a casing that was printed using 3D technology. The thickness of the single print layers was $0.09 \mathrm{~mm}$. This technology applies high-impact polystyrene (HIPS) material, which is an easy-mold polystyrene that can be applied for producing large items. A Zortrax M200 printer (Zortrax S.A, Olsztyn, Poland) with Z-Suite software (Zortrax S.A, Olsztyn, Poland) was utilized to print the case. One of the walls was removed from the printed housing so as to install a proton exchange membrane (PEM). Nafion PF 117 (The Chemours Company, Wilmington, DE, USA), 183 $\mu \mathrm{m}$ thick, was used as the PEM. After installing the PEM, the casing was filled with a catholyte (aqueous $\mathrm{KOH}$ solution: $0.1 \mathrm{n}$ ). Subsequently, a cathode with a Ni-Co catalyst was immersed in the catholyte. The bottom of the casing had perforations and was connected to an air pump (Figure 1). During the operation of the MFC (Reactor 3), the cathode was aerated with the capacity of $10 \mathrm{~L} \cdot \mathrm{h}^{-1}$. Figure 1 shows a diagram and image of the casing made of HIPS with the cathode. 


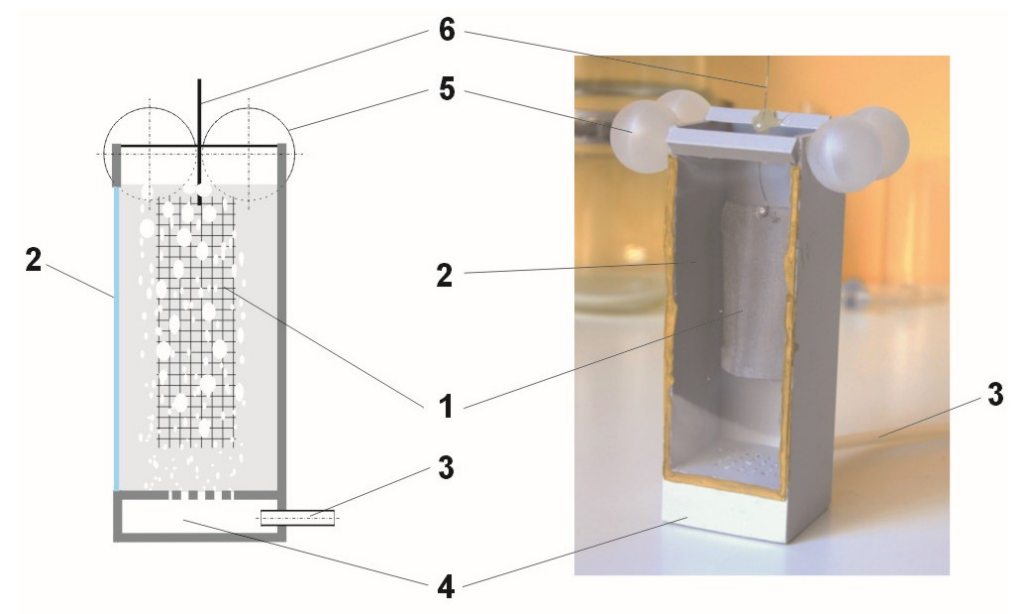

Figure 1. Cathode with casing made of high-impact polystyrene (HIPS): (a) cross section (schematic) 1: cathode with Ni-Co catalyst, 2: proton exchange membrane (PEM), 3: air supply, 4: air chamber, 5: float, 6: electrical connection; (b) housing with cathode and PEM.

The electrical circuit of the MFC was constantly connected with a $10 \Omega$ resistor. During the work of the MFC (Reactor 3), wastewater was not exchanged or refilled. A constant temperature of $298 \mathrm{~K}$ was maintained throughout the measurements. All reactors had the same dimensions (length/width/height: $40 \mathrm{~cm} \times 20 \mathrm{~cm} \times 20 \mathrm{~cm}$ ). Each reactor (Reactor 1, Reactor 2, and Reactor 3) was filled with wastewater with the volume of $15 \mathrm{~L}$. The third reactor performed the role of MFC because electrodes were installed in it. The measurements of the variations in COD were carried out at one-day intervals. The AMEL System 500 potentiostat (Amel S.l.r., Milano, Italy) with CorrWare software (Scribner Associates Inc, Southern Pines, NC, USA) and the Fluke 8840A multimeter (Fluke Corporation, Everett, WA, USA) was applied for the electrical measurements.

Figure 2 contains a diagram with the design of the third reactor, which played the role of MFC.

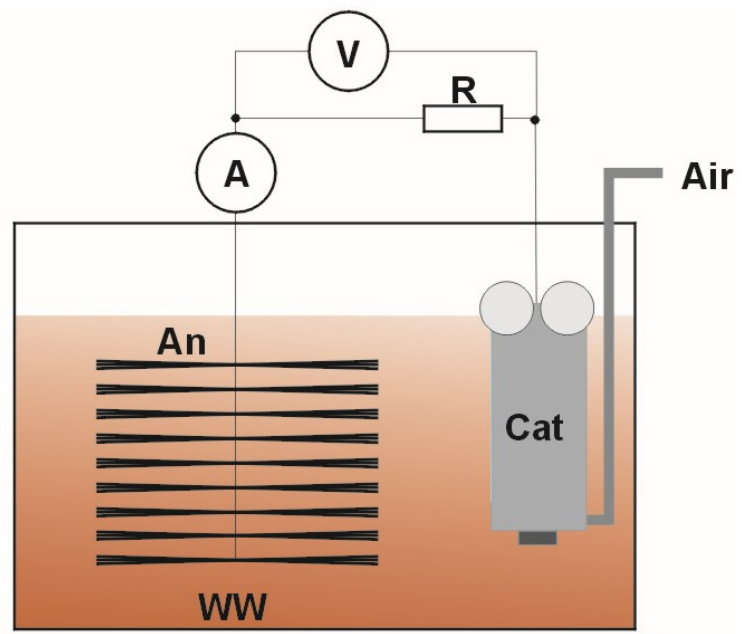

Figure 2. Diagram of microbial fuel cell (MFC) applied in the measurements. A: ammeter, V: voltmeter, R: load, An: anode, Cat: Ni-Co cathode in HIPS housing, WW: wastewater from a wastewater treatment plant in a yeast factory, Air: air supply.

\section{Results}

All objectives projected for the experimental research were accomplished, i.e., an Ni-Co catalyst was obtained, a reduction in COD for MFCs with cathodes with various percentages of nickel and cobalt was compared, alloy was identified for further tests, a comparison of the decrease in COD was 
made in the three reactors (one without aeration, one with aeration, and one with MFC), and MFC power curves were determined for all catalysts.

The data summarized in Figure 3 illustrates the reduction in COD concentration accompanying the conditions when MFC was in operation. These measurements were carried out for four catalysts that were obtained, which differed in terms of the nickel and cobalt content $(15,25,50$, and $75 \%$ of $C$ o). Wastewater was fed into MFC from the sewage treatment plant located at the yeast factory.

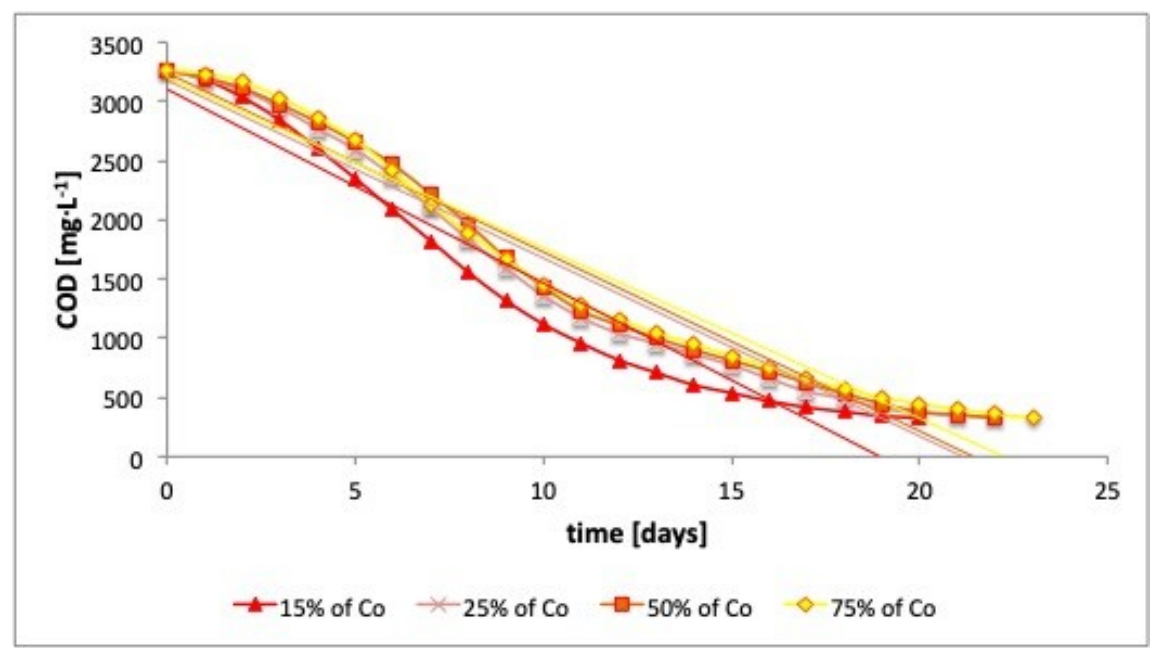

Figure 3. Reduction in chemical oxygen demand (COD) concentration resulting from the operation of our cathode designs with various compositions $(15,25,50$, and $75 \% \mathrm{Co})$. Colored curves mark the trend lines.

The trend lines provided grounds for the direct assessment of alloys in terms of the efficiency of COD reduction. On the basis of these results, an alloy with $15 \%$ Co content was selected for further measurements.

The curve in Figure 4 shows how the concentration of COD decreased in the three reactors: one without aeration, one with aeration, and one with the working MFC with a Ni-Co cathode $(15 \% \mathrm{Co})$. All reactors were immersed in wastewater from the wastewater treatment plant located on the factory premises.

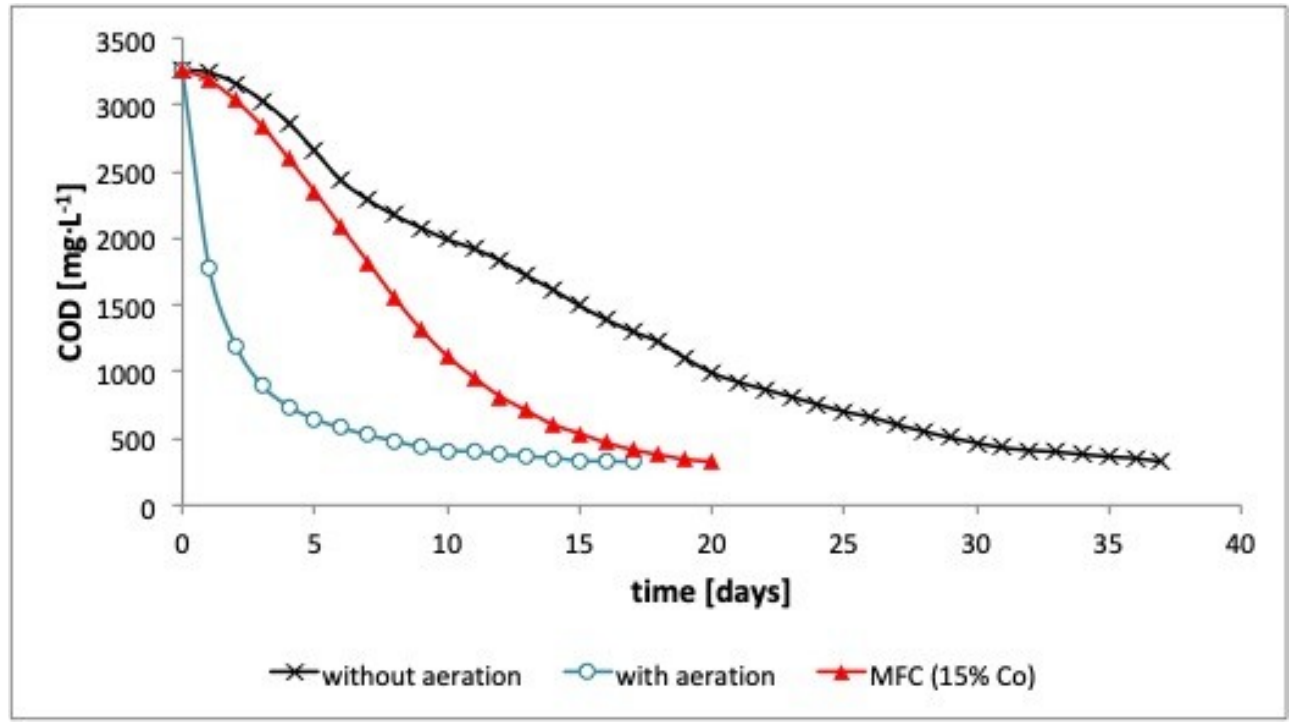

Figure 4. Comparison of the decrease in COD in a reactor with aeration, one without aeration, and one with a working MFC with a Ni-Co cathode (15\% Co). 
A removal level of COD by $90 \%$ was recorded in all reactors (Reactor 1 , Reactor 2, and Reactor 3 ) (Figure 4).

On the basis of the voltage and current measurements in a working MFC, MFC power curves were determined. The MFC power curves derived from wastewater treatment plants in the yeast factory are presented in Figure 5. These curves were determined for four cathode catalysts (Ni-Co), which differed in terms of alloy composition $(15,25,50$, and $75 \%$ of $\mathrm{Co})$.

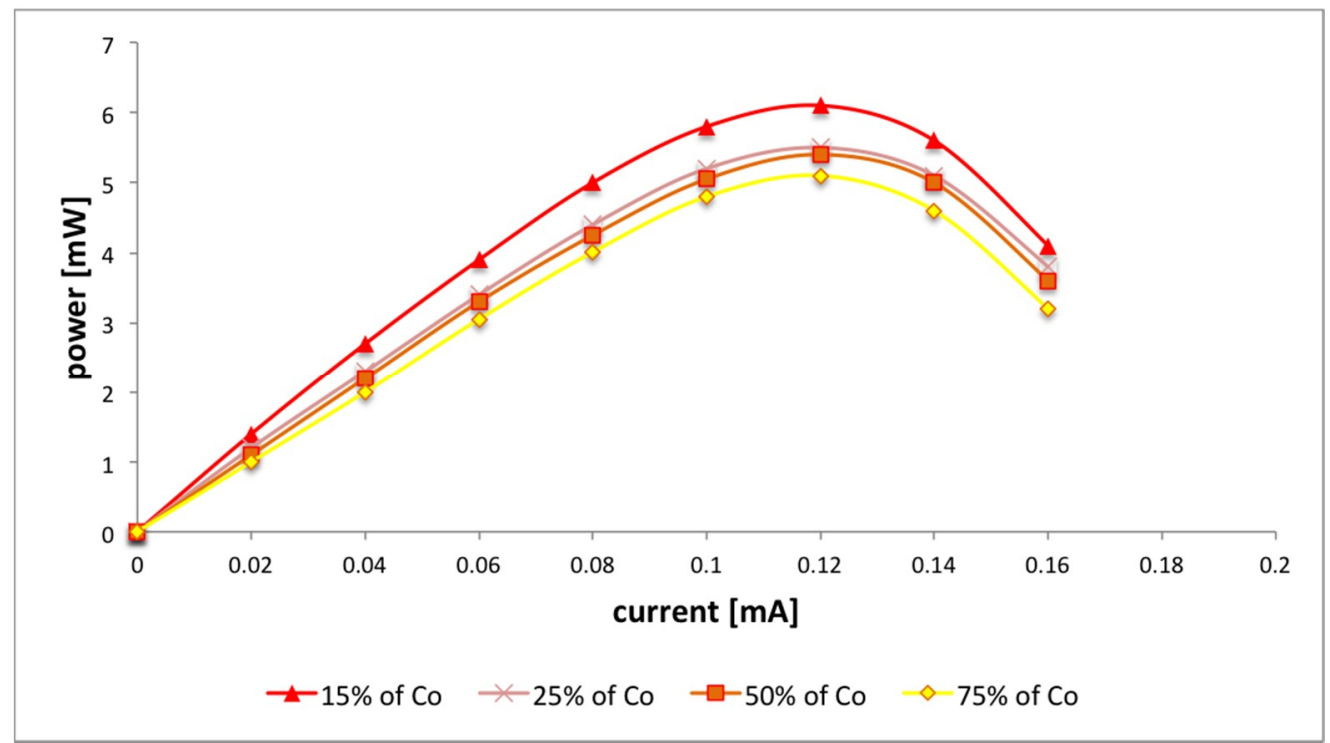

Figure 5. Power curves of microbial fuel cell (MFC) fed by wastewater from a wastewater treatment plant in a yeast factory. The content of Co in the catalyst was equal to $15,25,50$, and $75 \%$.

\section{Discussion}

The projected level of the decrease in COD equaled to $90 \%$ as recorded in all reactors (Reactor 1 , Reactor 2, and Reactor 3). Four Ni-Co alloys were analyzed as the cathode catalysts in the work of MFC (Reactor 3). These alloys differed in terms of the percentage ratio of alloy components (Ni and $\mathrm{Co}$ ). The characteristics of the curves representing the removal rate of COD for the catalysts comprising 25, 50, and 75\% Co were found to be very similar (Figure 3).

However, the curve developed for the drop in COD in the alloy with the $15 \%$ Co content took on a different course. This alloy offered the shortest time needed for the reduction in COD, which was equal to 20 days. In addition, the characteristic of the curve for this alloy (marked in red in the figures) was the most beneficial as COD removal was the fastest over the entire range of the measurements. Alloys with 25 and $50 \%$ Co ratio provided a $90 \%$ reduction in COD over a period of 22 days. However, for the alloy containing 75\% Co, the time needed for the adopted COD removal rate was 23 days. Due to the shortest COD removal time (20 days), the alloy comprising 15\% Co was selected for further measurements.

The next phase involved a comparison of the efficiency of COD reduction in the following reactor designs: one without aeration (Reactor 1), one with aeration (Reactor 2), and one that played the role of MFC (Reactor 3) (Figure 4). The analysis of these data showed that COD reduction by $90 \%$ in the microbiological fuel cell was very similar to the duration of time needed for the COD reduction in the reactor with aeration. Curve characteristics were more favorable for aeration; however, the difference was only three days. It can be noted that for the reduction in COD in the analyzed MFC (Reactor 3), an additional supply of oxygen (from the air) was only necessary for oxygenation of the cathode. This value was 27 times lower than the amount of air supplied to oxygenate Reactor 2.

The power and volume of generated electricity were determined on the basis of these measurements. During the MFC operation, the maximum power was obtained in the range of 
5.1-6.1 $\mathrm{mW}$ (Figure 5). The maximum volume of energy that was generated by the working MFC comprising a cathode including $15 \%$ of Co (20 days) was $1.27 \mathrm{Wh}$. These values are similar to the results recorded in other MFCs $[6,15-18,38,39]$. However, when we compare these results with the values recorded in the working MFC (with the Ni-Co cathode) that was fed by municipal sewage, we can note that the use of yeast waste resulted in the production of much larger amount of energy [39,43]. However, it is difficult to compare these results directly as previous studies concerned with $\mathrm{Ni}-\mathrm{Co}$ catalyst did not have the cathode immersed in the catholyte; moreover, only an alloy comprising $50 \%$ Co was analyzed $[39,43]$.

\section{Conclusions}

The measurements conducted for the purpose of the present study demonstrate that the catalytic activity of the Ni-Co alloy increases along with the increase in the volume ratio of nickel (Ni) in this alloy. Although the power and amount of energy generated by the system are small, the use of MFC can be considered as an additional process of treating sewage, which provides an opportunity to generate small amounts of electricity before the final treatment of wastewater in a treatment plant. It should be noted, however, that the volume of wastewater in a single reactor was equal to only $15 \mathrm{~L}$. In the tested MFC comprising a Ni-Co cathode, the maximum electrical output of $6.1 \mathrm{~mW}$ and $1.27 \mathrm{Wh}$ was generated over the period when the cells operated for 20 days. This paper demonstrates the possibility of utilizing Ni-Co alloy $(85 \% \mathrm{Ni}, 15 \% \mathrm{Co})$ as a cathode catalyst in a working MFC applied for wastewater treatment in a sewage treatment plant in a yeast factory. Therefore, this wastewater can be considered as a potential source of energy to be used for the internal demand of the plant and not only as a problematic type of waste.

Author Contributions: Data curation, B.W.; Investigation, P.P.W. and B.W.; Methodology, P.P.W.; Supervision, P.P.W.

Funding: This research received no external funding.

Acknowledgments: This paper was realized as part of the cooperation between Opole University and Lesaffre Polska yeast factory. This study was possible as part of the scientific internship performed by the authors in Lesaffre Polska factory.

Conflicts of Interest: The authors declare no conflict of interest.

\section{Nomenclature}

$\begin{array}{ll}\text { AF } & \text { agricultural fields } \\ \text { An } & \text { anode } \\ \text { Cat } & \text { cathode } \\ \text { COD } & \text { chemical oxygen demand } \\ \text { DWW } & \text { domestic wastewater } \\ \text { HIPS } & \text { high impact polystyrene } \\ \text { IWW } & \text { industrial wastewater } \\ \text { MFC } & \text { microbial fuel cell } \\ \text { PEM } & \text { proton exchange membrane } \\ \text { PWW } & \text { process wastewater } \\ \text { WW } & \text { wastewater } \\ \text { WWTP } & \text { wastewater treatment plant }\end{array}$

\section{References}

1. Gallouj, F.; Weber, K.M.; Stare, M.; Rubalcaba, L. The futures of the service economy in Europe: A foresight analysis. Tech. Forecast. Soc. Chang. 2015, 94, 80-96. [CrossRef]

2. Menrad, K. Market and marketing of functional food in Europe. J. Food Eng. 2003, 56, 181-188. [CrossRef]

3. Arvanitoyannis, I.S. Waste Management for the Food Industry; Elsevier: Amsterdam, The Netherlands, 2010.

4. Cecconet, D.; Molognoni, D.; Callegari, A.; Capodaglio, A.G. Agro-food industry wastewater treatment with microbial fuel cells: Energetic recovery issues. Int. J. Hydrog. Energy 2018, 43, 500-511. [CrossRef] 
5. Barbera, M.; Gurnari, G. Wastewater Treatment and Reuse in the Food Industry; Springer: Cham, Switzerland, 2018.

6. Logan, B. Microbial Fuel Cells; Wiley: Hoboken, NJ, USA, 2008.

7. Ravindran, R.; Jaiswal, A.K. Exploitation of food industry waste for high-value products. Trends Biotechnol. 2016, 34, 58-69. [CrossRef] [PubMed]

8. Cusick, R.D.; Kim, Y.; Logan, B.E. Energy capture from thermolytic solutions in microbial reverse-electrodialysis cells. Science 2012, 335, 1474-1477. [CrossRef] [PubMed]

9. Utilization of By-Products and Treatment of Waste in the Food Industry; Oreopoulou, V., Russ, W., Eds.; Springer: New York, NY, USA, 2007.

10. Russ, W.; Meyer-Pittroff, R. Utilizing waste products from the food production and processing industries. Critical Rev. Food Sci. Nutr. 2010, 44, 57-62. [CrossRef] [PubMed]

11. Muszyńska, B.; Mirosław Malec, M.; Sułkowska-Ziaja, K. Medicinal and cosmetological properties of Saccharomyces Cerevisiae. Postepy Fitoterapii 2013, 1, 54-62.

12. Paruch, A.M.; Pulikowski, K.; Bawiec, A.; Pawęska, K. Assessment of Groundwater Quality in Areas Irrigated with Food Industry Wastewater: A Case of Wastewater Utilisation from Sugar and Yeast Factories. Envir. Process. 2017, 4, 799-812. [CrossRef]

13. Begea, M.; Berkesy, C.; Berkesy, L.; Cîrîc, A.; Bărbulescu, I.D. Study of the recovery in agriculture of the waste resulted from baker's yeast industry. Adv. Agric. Botanics 2017, 9, 136-145.

14. Davis, J.B.; Yarbrough, H.F., Jr. Preliminary experiments on a microbial fuel cell. Science 1962, 137, 615-616. [CrossRef] [PubMed]

15. Franks, A.E.; Nevin, K.P. Microbial fuel cells, a current review. Energies 2010, 3, 899-919. [CrossRef]

16. Min, B.; Logan, B.E. Continuous electricity generation from domestic wastewater and organic substrates in a at plate microbial fuel cell. Environ. Sci. Technol. 2004, 38, 5809-5814. [CrossRef] [PubMed]

17. Min, B.; Cheng, S.; Logan, B.E. Electricity generation using membrane and salt bridge microbial fuel cells. Water Res. 2005, 39, 1675-1686. [CrossRef] [PubMed]

18. Wang, X.; Feng, Y.J.; Lee, H. Electricity production from beer brewery wastewater using single chamber microbial fuel cell. Water Sci. Technol. 2008, 57, 1117-1121. [CrossRef] [PubMed]

19. Rabaey, K.; Verstraete, W. Microbial fuel cells: Novel biotechnology for energy generation. Trend. Biotechnol. 2005, 23, 291-298. [CrossRef] [PubMed]

20. Logan, B.E.; Hamelers, B.; Rozendal, R.; Schroder, U.; Keller, J.; Verstraete, W.; Rabaey, K. Microbial Fuel Cells: Methodology and Technology. Environ. Sci. Technol. 2006, 40, 5181-5192. [CrossRef] [PubMed]

21. Bond, D.R.; Lovley, D.R. Electricity production by Geobacter sulfurreducens attached to electrodes. Appl. Envir. Microbiol. 2003, 69, 1548-1555. [CrossRef]

22. Chaudhuri, S.K.; Lovley, D.R. Electricity generation by direct oxidation of glucose in mediatorless microbial fuel cells. Nat. Biotechnol. 2003, 21, 1229-1232. [CrossRef] [PubMed]

23. Kim, H.J.; Park, H.S.; Hyun, M.S.; Chang, I.S.; Kim, M.; Kim, B.H. A Mediator-Less Microbial Fuel Cell Using a Metal Reducing Bacterium, Shewanella Putrefaciens. Enzym. Microb. Technol. 2002, 30, 145-152. [CrossRef]

24. Park, H.S.; Kim, B.H.; Kim, H.S.; Kim, H.J.; Kim, G.T.; Kim, M.; Chang, I.S.; Park, Y.K.; Chang, H.I. A novel electrochemically active and $\mathrm{Fe}(\mathrm{III})$-reducing bacterium phylogenetically related to Clostridium butyricum isolated from a microbial fuel cell. Anaerobe 2001, 7, 297-306. [CrossRef]

25. Pham, C.A.; Jung, S.J.; Phung, N.T.; Lee, J.; Chang, I.S.; Kim, B.H.; Yi, H.; Chun, J. A novel electrochemically active and $\mathrm{Fe}(\mathrm{III})$-reducing bacterium phylogenetically related to Aeromonas hydrophila, isolated from a microbial fuel cell. FEMS Microbiol. Lett. 2003, 223, 129-134. [CrossRef]

26. Bond, D.R.; Lovley, D.R. Evidence for involvement of an electron shuttle in electricity generation by Geothrix fermentans. Appl. Environ. Microbiol. 2005, 71, 2186-2189. [CrossRef] [PubMed]

27. Reguera, G.; McCarthy, K.D.; Mehta, T.; Nicoll, J.S.; Tuominen, M.T.; Lovley, D.R. Extracellular electron transfer via microbial nanowires. Nature 2005, 435, 1098-1101. [CrossRef] [PubMed]

28. Reguera, G.; Nevin, K.P.; Nicoll, J.S.; Covalla, S.F.; Woodard, T.L.; Lovley, D.R. Biofilm and nanowire production leads to incre- ased current in Geobacter sulfurreducens fuel cells. Appl. Environ. Microbiol. 2006, 72, 7345-7348. [CrossRef] [PubMed] 
29. Patil, S.A.; Surakasi, V.P.; Koul, S.; Ijmulwar, S.; Vivek, A.; Shouche, Y.S.; Kapadnis, B.P. Electricity generation using chocolate industry wastewater and its treatment in activated sludge based microbial fuel cell and analysis of developed microbial community in the anode chamber. Bioresour. Technol. 2009, 100, 5132-5139. [CrossRef] [PubMed]

30. Zhang, X.; Cheng, S.; Huang, X.; Logan, B.E. Improved performance of single-chamber microbial fuel cells through control of membrane deformation. Biosens. Bioelectron. 2010, 25, 1825-1828. [CrossRef] [PubMed]

31. Aelterman, P.; Freguia, S.; Keller, J.; Verstraete, W.; Rabaey, K. The anode potential regulates bacterial activity in microbial fuel cells. Appl. Microbiol. Biotechnol. 2008, 78, 409-418. [CrossRef] [PubMed]

32. Juang, D.F.; Lee, C.H.; Hsueh, S.C.; Chou, H.Y. Power generation capabilities of microbial fuel cells with di erent oxygen supplies in the cathodic chamber. Appl. Biochem. Biotechnol. 2012, 167, 714-731. [CrossRef] [PubMed]

33. Angenent, L.T.; Karima, K.; Al-Dahhan, M.H.; Wrenn, B.A.; Domíguez-Espinosa, R. The wastewater from yeast factory was used in measurements. Production of bioenergy and biochemicals from industrial and agricultural wastewater. Trend. Biotechnol. 2004, 22, 477-485. [CrossRef] [PubMed]

34. Verstraete, W.; Morgan-Sagastume, F.; Aiyuk, S.; Rabaey, K.; Waweru, M.; Lissens, G. Anaerobic digestion as a core technology in sustainable management of organic matter. Water Sci. Technol. 2005, 52, 59-66. [CrossRef] [PubMed]

35. Tsai, H.Y.; Wu, C.C.; Lee, C.Y.; Shih, E.P. Microbial fuel cell performance of multiwall carbon nanotubes on carbon cloth as electrodes. J. Power Source 2009, 194, 199-205. [CrossRef]

36. Dumas, C.; Mollica, A.; Féron, D.; Basséguy, R.; Etcheverry, L.; Bergel, A. Marine microbial fuel cell: Use of stainless steel electrodes as anode and cathode materials. Electrochim. Acta 2006, 53, 468-473. [CrossRef]

37. Martin, E.; Tartakovsky, B.; Savadogo, O. Cathode materials evaluation in microbial fuel cells: A comparison of carbon, $\mathrm{Mn}_{2} \mathrm{O}_{3}, \mathrm{Fe}_{2} \mathrm{O}_{3}$ and platinum materials. Electrochim. Acta 2011, 58, 58-66. [CrossRef]

38. Włodarczyk, B.; Włodarczyk, P.P. Microbial fuel cell with $\mathrm{Cu}-\mathrm{B}$ cathode powering with wastewater from yeast production. J. Ecol. Eng. 2017, 18, 224-230. [CrossRef]

39. Włodarczyk, B.; Włodarczyk, P.P. Use of Ni-Co alloy as cathode catalyst in single chamber microbial fuel cell. Ecol. Eng. 2017, 18, 210-216. [CrossRef]

40. Włodarczyk, P.P.; Włodarczyk, B. Possibility of Using Ni-Co Alloy as Catalyst for Oxygen Electrode of Fuel Cell. Chin. Bus. Rev. 2015, 14, 159-167. [CrossRef]

41. Włodarczyk, P.P.; Włodarczyk, B. Ni-Co alloy as catalyst for fuel electrode of hydrazine fuel cell. China-USA Bus. Rev. 2015, 14, 269-279. [CrossRef]

42. Huggins, T.; Fallgren, P.H.; Jin, S.; Ren, Z.J. Energy and performance comparison of microbial fuel cell and conventional aeration treating of wastewater. J. Microb. Biochem. Technol. 2013, S6-002. [CrossRef]

43. Włodarczyk, B.; Włodarczyk, P.P.; Kalinichenko, A. Single chamber microbial fuel cell with Ni-Co cathode. In Proceedings of the International Conference Energy, Environment and Material Systems (EEMS 2017), Polanica Zdrój, Poland, 13-15 September 2017.

(C) 2018 by the authors. Licensee MDPI, Basel, Switzerland. This article is an open access article distributed under the terms and conditions of the Creative Commons Attribution (CC BY) license (http://creativecommons.org/licenses/by/4.0/). 